\title{
EVALUATING THE SINCERITY OF TURKISH MEDIA CONCERNING THE STRUGGLE AGAINST SUBSTANCE USE AND ADDICTION: THE "BARON" DISCOURSE ${ }^{1}$
}

\author{
Şakir EŞİTTİ \\ Ardahan University, Turkey \\ sakiresitti@yahoo.com \\ https://orcid.org/0000-0001-9270-5363 \\ Mehmet IŞIK \\ Mardin Artuklu University, Turkey \\ mehmet.isik@artuklu.edu.tr \\ https://orcid.org/0000-0002-1682-2610
}

\begin{abstract}
This study questions the sincerity of Turkish media concerning its support for the struggle against substance use and addiction within the framework of the concept "baron" and aims to reveal with which lingual and discourse-related strategies the concept of "baron" is circulated. In this scope, news about people who smuggle a massive amount of drugs, published between January-November 2006 on the websites of the three top-seller newspapers, Hürriyet, Sözcü, and Sabah, are analyzed within the framework of the critical discourse analysis developed by Teun A. Van Dijk. The results of the analysis reveal that the news about people who smuggle drugs and who are named as "barons" by the Turkish media are transferred to the reader with an encouraging and exaggerated use of language, that drug trafficking is represented as a quite lucrative and adventurous profession which provides opportunities to quickly promote or possess fame and fortune, that instead of focusing on personal, social, and economic problems caused by drug trafficking, the problem is decontextualized by putting the emphasis on individual success stories of barons, the magnitude of smuggling, how cunning the smugglers are, how they could escape from prison or how they lived in their ordinary lives. While the media uses the term "poison merchant" even for kids who are pushed to criminal activities concerning narcotics/stimulants, the preference of the concept "baron" when it's about people who engage in massive amounts of drug trafficking reveals a necessity to question the media's sincerity concerning the struggle against substance use and addiction.
\end{abstract}

Keywords: substance use, substance addiction, baron, poison merchant, discourse analysis

\section{MADDE KULLANIMI VE MADDE BAĞIMLILIĞIYLA MÜCADELEDE TÜRK MEDYASININ SAMIMIYETININ DEĞERLENDİRILMESİ: "BARON" SÖYLEMI ÖRNEĞİ}

\section{ÖZ}

Bu çalışma Türk medyasının madde kullanımı ve bağımlılığı ile mücadeleye destek konusundaki samimiyetini Baron kavramı çerçevesinde sorgulamakta ve baron kavramının hangi dilsel ve söylemsel stratejilerle dolaşıma sokulduğunu ortaya koymayı amaçlamaktadır. Bu kapsamda en yüksek tiraja sahip üç gazete olan, Hürriyet, Sözcü ve Sabah gazetelerinin internet sitelerinde Ocak-

\footnotetext{
${ }^{1}$ This article is prepared in the light of the bulletin text titled "Evaluating The Sincerity Of Turkish Media Concerning The Struggle Against Substance Use And Addiction: The 'Baron' Discourse”, which was presented in the II. Health Communication Symposium on November 4, 2016 in Eskişehir, full text of the article is not published before.
} 
Kasım 2016 döneminde büyük miktarda uyuşturucu kaçakçılığ yapan kişilere ilişkin haberler, Teun A. Van Dijk'ın geliştirdiği eleştirel söylem çözümlemesi modeli çerçevesinde çözümlenmiştir. Çalışmada elde edilen verilere göre büyük miktarlarda uyuşturucu/uyarıcı madde kaçakçılığı yapan ve Türk Medyası tarafından "baron" olarak adlandırılan kişilerle ilgili haberlerin okuyucuya oldukça magazinsel ve özendirici bir dille, abartılarak aktarıldığı tespit edilmiştir. Uyuşturucu ile ilgili yapılan haberlerde Uyuşturucu kaçakçıllğının yarattı̆̆ bireysel, toplumsal ve ekonomik sorunlara eğilmek yerine "baronların" bireysel yaşam ve başarı öykülerine, yaptıkları uyuşturucu kaçakçılığının büyüklüğüne, kurnazlıklarına, hapishanelerden nasıl kaçtıklarına ya da nasıl yakalandıklarına ilişkin bilgiler verildiği; böylelikle sorunun bağlamından uzaklaştırıldığı sonucuna ulaşılmıştır. Aynı medyanın, küçük miktarlarda uyuşturucu/uyarıcı madde satan kişiler hatta suça itilen çocuklar için bile "zehir taciri" ifadesini kullanması ise medyanın madde kullanımı ve bağımlılığı ile mücadele konusundaki samimiyetini sorgulamaya açmaktadır. Başka bir ifade ile "baron" söylemi, Türk medyasının madde kullanımı ve bağımlılı̆̆ koyan bir turnusol kâğıdı niteliği taşımaktadır.

Anahtar kelimeler: Madde kullanımı, madde bağımlılı̆̆l, baron, zehirli ticaret, söylem analizi

\section{INTRODUCTION}

Substance use and addiction are among most important problems both in Turkey and worldwide. The developments in the new communication technologies result in a more interactive information and communication of people as social beings, people can satisfy their certain social and psychological needs in a faster and cheaper way through the new media as opposed to conventional methods (Eşitti, 2013). On the other hand, these developments in communication sector along with their positive influences have certain negative effects on almost all groups of the society-especially on the youngster - and can lead an increasing number of people to a substance of addiction. Like in the rest of the world, There is a significant increase in substance use in Turkey recently (Işık, 2013: 1, Işık and Erdal: 464).

According to the UN data in 2014, one in every 20 adults or a quarter billion people between the ages 15-64 used at least one narcotic or stimulant drug. $12 \%$ of drug addicts — which means over 29 million people - appear to suffer health issues due to drug use. While marijuana, the drug is used by 183 million people around the world, and continues to be the most common drug in 2014, followed by the amphetamines. Opiates and prescribed opiates with 33 million users-although not as commonly used as marijuana - occupy the third place as substances with the greatest potential health risk (UNODC, 2016: 1).

Like the rest of the world, substance use and addiction constitute a critical problematic area in Turkey. 8145 household residents are interviews in the 2011 study by TUBIM ${ }^{2}$. The study revealed that lifelong substance use ratio was $2.7 \%$. In the result of the study, within the age group 15-24 it is observed that being male, single, paid less than $500 \mathrm{TL}(<200 €$ when the research was conducted) per month, consuming tobacco, alcohol or any drugs that are not among the recommendations of the doctor seriously increased drug use (TUBİM, 2014: 37).

With the increase of substance use and addiction, while on one hand the role of media is debated in rendering this problem a bigger issue each day, on the other hand, it is also a question to what extend media can contribute to the struggle against substance use and addiction. These debates were reflected also in Turkey's agenda, and in 2007 in accordance with the prescribed goals in National Strategy Document, with the presence of representatives from preventive institutions concerning the struggle against substance use and media institutions, project Audiovisual Media's Role in Substances and

\footnotetext{
${ }^{2}$ Türkiye Uyuşturucu ve Uyuşturucu Bağımlılı̆̆ İzleme Merkezi: Turkey Center For Monitoring Drugs and Drug Addiction
} 
Substance Use was founded in order to increase the number of programs which possibly contain the most appropriate messages in media, especially to provide the transmission of inappropriate signals to each social class and hence to contribute to the struggle against substance use and addiction (EMCDDA, 2007: 27; Ünüvar, 2008: 289). Later, without anyhow referring to the former, the project was once again put into practice in 2010 (TUBİM, 2011: 62-63).

Within the scope of the project mentioned, TUBİM and RTÜK published in collaboration a booklet specifying the instructive principles. While Ahmet Pek, Mustafa Pınarcı, Bülent Demirci, and Dilek Ayhan from TUBİM and Nurullah Öztürk, Nuran Yardımc1, Aygen Emirhan, and Melike Diler from RTÜK participated as authors; TUBIM Science Committee academicians, experts from Ministry of National Education, Ministry of Health, and Organization of Social Services and Child Care contributed to the preparing of the preface of the booklet with the same title as the project.

In the introduction of the booklet instructive principles and goals are specified as such: "The instructive principles in this booklet were prepared in the search of the baseline of a publishing policy that includes supportive solutions which will strengthen the coalition, the scientific approach that functions as both constructive and informative, and raising awareness" (Pek et al., 2010: 9). Along with remarking that media employees have "certain lack of knowledge" concerning substance use and addiction as a delicate issue (Pek et al., 2010: 3), the preparing of the booklet as merely for audiovisual media leaving out the printed press and the internet is another significant deficiency in today's societies where new media technologies keep developing. Besides, it is clearly stated in the booklet that there is a specific expectation from employees in television sector to act sensitively:

This informative booklet which will provide the satisfaction of a significant need for information of actors in the media sector was welcomed with great enthusiasm and satisfaction by Association of Television Publishers. We hope that TV institutions and publishers with the help of this information will broadcast more sensitively and cautiously on this subject which already is quite a sensitive one

Considering the fight against substance use and addiction, a problem that everyone agrees for the solution of which media has great responsibilities, the statement of an exception of sensitive action from television employees which constitutes only a certain part of media, hence excluding other media employees from the fight against substance use and addiction is a problematic approach.

Audiovisual Media's Role in Substances and Substance Use, although prepared only for audiovisual media, the principles that the booklet finds necessary to follow are oriented at media as a whole. One of the most important principles is the necessity to not to use the word "baron for substance trafficking organization leaders" due to its promotive potential. In documents like Audiovisual Media's Role in Substances and Substance Use, as well as the later published Communication Strategy Application Guide For The Fight Against Drugs Action Plan (2015) and in activities conducted, although it is advised not to use the term "baron" which is evaluated to be encouraging and promotive for people who smuggle great amounts of narcotics and stimulant drugs, both audiovisual and printed media insist on using the term.

As is known, the term "baron" is an important title in the Feudal hierarchy. In the hierarchy that consists of the knight, baron, viscount, count, marquis, duke (lord) and finally the king the title baron that stands in between knight and viscount (Aydoğdu, 205: 4), and continues to be used as an expression of nobility still in today. The use of such an aristocratic title by the media for people who smuggle massive amounts of narcotic and stimulant drugs is a problematic discourse. The sincerity of the same media becomes open to questioning when it uses the expression "poison merchant" for people who smuggle small amounts of drugs even including small children who are forced to do so. Put in another way, the term "baron" functions as a litmus paper concerning the Turkish media's sincerity/insincerity in the fight against substance use and addiction.

Submit Date: 07.04.2018, Acceptance Date: 20.07.2018, DOI NO: 10.7456/10804100/009 
This study questions the sincerity of the Turkish media's support to the struggle against substance use and addiction within the scope of the term "baron" and aims to reveal through which lingual and discourse-related strategies the concept is put into circulation.

\section{TURKISH DRUG SMUGGLERS ON INTERNATIONAL SCALE}

Turkey, ever since the Ottoman era has always been criticized due to being one of the most important producers of opium poppy, the raw material of illegal drugs like morphine and heroine; along with some other legal drugs. Sumerians and many other civilizations that followed them have cultivated these lands with substances like hemp, and particularly poppy, and usually used these for the curing of diseases. So did the Turks who started to settle in Anatolia in the 11th century, especially those who continued this farming for hundreds of years in central and western Anatolia. Not only Turks; Greeks and Armenians were heavily occupied with this farming, too. During these eras, growing poppy was not merely to produce opium. While its oil was used in cooking, the seeds were used as animal feed, and its stem was used in the making of adobe (Poroy, 1981: 196-197).

With the increasing demand for opium all around the world, the cultivation of the plant gained significance in the Ottoman Empire thus the state prepared supplemental bills for planting, growing, and harvesting of the plant (Çıtır, 2015: 24). The proliferation of opium in China and with the best quality opium growing in Western Anatolian soil ${ }^{3}$ made the Ottoman Empire one of the most important opium exporting states in the 19th century. The revenue of this transaction was on such a big scale that in 1826 similar to England government monopoly (Yed-i Vahid) was established in order to control opium transaction and to cover the costs of the newly founded Asakir-i Mansure- $i$ Muhammediye army (Poroy, 1981: 192-198). Under government monopoly, the production of poppy and the revenue from this production has increased (Gingeras, 2014: 56).

The Ottoman State, wishing to protect the ongoing profitable opium trade, became the only state who-though invited - did not attend the Shanghai Congress of 1909 despite the invitation and persistence of the United States, first international activity organized for the struggle against substance use (Inglis, 1975: 155); and did not sign the 1912 Hague International Opium Convention after attending the Hague Conference (Keefer and Loayza, 2010: 74-75). With the Ottoman State not signing the application of the convention became difficult and the Dutch had to organize another conference in May 1914. The United States proposed the signing of the convention by the Ottomans with coercion, but with the suggestion of England, it was decided to leave out the Ottoman State and Serbia from the application of the convention. This situation continued until the signing of the Sevres Treaty, and according to the article 280 of this treaty; the Ottomans were forced to promise to adhere to the agreement proposed in the Hague Opium Convention. The Republic of Turkey who successfully overcame the Independence War accepted to be a party of this convention according to the article 100 of Lozan Treaty (Erhan, 1996: 54; Erdinç, 2004: 32).

The young Republic of Turkey was interested in the subject matter of drugs ever since its foundation and attended to international activities concerning substance use. But with the concern of losing its revenues from opium production, although promised to sign international treaties, the new Turkish State abstained from signing or preferred not to vote on this subject matter until the 1930s. Instead, it made certain arrangements in the domestic law in the light of the conferences attended (Işsk, 2013: 60). Starting from the year 1924, poppy laboratories were opened in İstanbul and İzmir, soon after in 1926 in the building known as Mecidiye Barrack - where Divan Hotel stands today - a heroin factory named Oriental Products Company was founded with Japanese capital. This company that continued production until 1927 was followed by Ecza-yl Trbbiye ve Kimyeviye (ETKIM), founded by Nesim

\footnotetext{
${ }^{3}$ Anatolian poppy, also known as the blue poppy has always been a quite profitable agricultural product sought by all pharmaceutical companies around the world due to its high morphine content of 15-17\% (Erdinç, 2004: 44).
} 
Taranto in May 1929 in Eyüp, İstanbul, and Türk Ecza-yı Tıbbiye ve Kimyeviye (TEKTAŞ) founded with French capital in December 1929 in Kuzguncuk, İstanbul; both of which continued production until 1933 (Gürsoy, 2007: 47). The activities of these companies disturbed many states, especially America, and with the provocation of monopoly companies in pharmacy industry like La Roche and G.H. Boehringer Turkey was instantly seen as the main source of illegal heroin in the world and thus was accused (Işık, 2013: 60).

President Veteran Mustafa Kemal Atatürk investigated these accusations in considering warnings delivered to himself and noticed the damage that heroin trade gave to Turkey's reputation, and the hazards due to the proliferation of the use of the substance. Thus together with the cabinet officers, on 26 December 1932, he declared that Turkey would comply with the Hague Protocol of 1912 and Geneva Convention for Limiting the Manufacture and Regulation the Distribution of Narcotic Drugs of 1925 and 1931. Turkey's decision was welcomed with pleasure in the USA, and the New York Times newspaper praised Turkey's attitude in a news article titled "Christmas Gift to the USA" (Erhan, 1996: 72). Besides, Pennsylvania Senator James J. Davis, in his speech of 3 January 1933, stated "All the states of the world, especially America, got an astonishing Christmas present today with the imposition of a ban on narcotic substances by the President of Turkey Veteran Mustafa Kemal" in expressing his satisfaction due to Turkey's decision (Goloğlu, 2010: 232-233).

With the law amendment made in the same year on 14 January 1933, according to the article 2108 Turkey recognized 1912 Hague, 1925, and 1931 Geneva Conventions and in accordance with the law no. 2253 on 12 June 1933 a "Monopoly of Narcotic Substances" under the Ministry of Economy was founded. By operation of this law, in accordance with the statutory decree no. 14829 cultivation areas of the plant were limited and taken under government control on 10 August 1933. According to this decree, only 17 cities in Turkey was allowed to engage in poppy agriculture. In 24 June 1938 the purchase, price-fixing, and sale of the poppy were handed over to Soil Products Office according to the law no. 3491. In accordance with this law, the export of by-products of poppy and the import of poppy alkaloids was assigned to the control of the office (Çolak, 2013: 518). By means of the precautions taken by the president Atatürk, after the closing of heroin factories and monopolization of poppy production through legal arrangements Turkey has not been subject to criticism due to opium cultivation and trade although it still engaged in the production of 55\% of world's legal poppy production for a while (Iş̧1k, 2014: 64). But the Democratic Party regime did not continue the application commenced in Atatürk's era, and on 18 April 1951 according to the law no. 5759 set the trade of poppy within the country free as long as the final transaction point was the office. The freeing of poppy trade, due to smugglers offering higher producers than the government does to producers, caused smuggling to quickly increase (Erhan, 1996: 85). In the face of this situation, the number of penalties given to production, import and export of drugs in the Turkish Penal Code was increased, and moreover, for those who commit drugs-related crimes in forming gangs death sentence was foreseen. However the increasing of fines elevated opium prices in the illegal market hence caused smuggling to increase even more ${ }^{4}$ (Songar, 1974: 35, Erdinç, 2004: 160). Thus, drug smuggling that reached from Turkey to France and then to America has become an increasingly significant problem in Turkey-America relations.

The first step of the illegal opium trade in Turkey was intermediaries who bought the opium from villagers at retail. These intermediaries sold the opium in shipments of 300-1000 kilograms to

\footnotetext{
${ }^{4}$ The increase in smuggling caused the poppy to once again become the truce of tension in Turkish-American relationships. This tension resulted in total prohibition of poppy cultivation and opium production by the Nihat Erim Government who no longer could stand the increasing pressure implemented by America, on 29 June 1971 according to the decree no. 5/2654 (Zurcher, 2011: 395). The ban on cultivating poppy, one of the most important agenda items of the 1971 general elections was lifted by CHP-MSP coalition government on 1 July 1974 and the cultivation of the poppy was allowed only in places determined by the cabinet under government control. The harvest that before was carried out by splitting the poppy seed pods was totally prohibited and instead the pods started to be directly bought by Soil Products Office without splitting and sent for processing to the alkaloid factory built in Bolvadin in 1981 (Erhan, 1996: 138-141, Işık, 2014: 64).
} 
merchants in Ankara and İstanbul, who transported the opium first to Lebanon through Syria and after converting to morphine, to heroin laboratories in Marseilles (Parlar, 2006: 96). After the breaking of the French connection in 1964 when famous Corsican heroin producer Joseph Cesari was caught during production in his laboratory near Marseilles (Erdinç, 2004: 168-169), drug dealers and gangs of Turkey origin became more organized than they were, and gained enormous strength by eliminating certain intermediaries. The gangs who launched the base morphine they started to produce in Turkey to the market both from major ports like in İstanbul and İzmir and from minor ones like Bandirma, started to prefer land route in the early 1970s when problems with seaways occurred. This choice was also a result of the developing highways, the increase in the number of vehicles and the number of Turkish employed in Europe (Parlar, 2006: 96).

Starting from the 1950s, the transformation of local smugglers first to regional than to international suppliers made it possible for "papas" who have escalated by means of ethnic or citizenship-related relations to involve in worldwide organizations with the support of services, politicians and security forces. Hence opium has become the driving force for unobtrusive local smugglers of Anatolia to evolve into significant figures of illegal "drugs market" throughout the 60s (Erdinç, 2004: 195).

In 1970s Turkish drug merchants and gangs became more famous in the international arena. In 1970, Justice Party member of parliament Zekeriya Kürşat was caught with 4.5 kilograms of drugs in Sweden, but was able to escape during the investigation. It became a diplomatic scandal when Nationalist Movement Party Niğde senator Kudret Bayhan was caught trying to smuggle 146 kilograms of heroin to France on 6 March 1972 with his Anadolu model car. Later it was revealed that another member of parliament, Sami Binicoğlu had also been involved in the case; and again in October 1978, former Nationalist Movement Party representative Halit Karaman was arrested for heroin smuggling in Duisburg and was sentenced to 7 years in jail (Erdinç, 2004: 167-168).

The research titled "The Heroin Trail" by American journalists Robert W. Greene, Les Payne and Knut Royce carried the magnitude of drug smuggling in Turkey and its international connections to the world's agenda. Published in Newsday newspaper and earned the three journalists Pulitzer award, the research aroused great curiosity in the American public opinion (Abrahams, 2005: 24-125). The three journalists in their research stated many names including famous businessmen like Ziya Kalkavan or politicians like Sami Binicioğlu who gained great amounts of money from drug smuggling (Erdinç, 2004: 185-189).

The first major drug smuggling operation was carried out in March 1973. In the scope of this first operation, also known as the "Papas Operation" many names of Turkish mafia controlling the drugs and arms smugglers like Syrian Akil Çubuklu, Garabet Sarkis Abriyan, Abuzer Uğurlu, Ali Bezal, Sefer Bezel, Mehmet Cantaş, Fahri Bank, Hayrettin Yağcı, Hacı Mirza, Zihni İpek and Mehmet Kaptanoğlu were judged. The "Second Papas Operation" started when six years after the former a smuggler named İbrahim Telemen called Uğur Mumcu and wrote and advice letter. The smugglers listed in Telemen's letter-except for Abuzer Uğurlu - were taken into custody the night of 16 April 1979 and were soon after released (Mumcu, 1993: 82-100; Erdinç, 2004: 190-193).

The "Papas Operation" continued with the state of siege manifestation declared on 13 October 1980, after the coup of 12 September. İstanbul State of Siege Commandership requested certain people suspected of smuggling incidents like Abuzer Uğurlu, Mustafa Uğurlu, Hacı Mirza, Osman İmamoğlu, Avni Karadurmuş, Nevzat Türköz, Bekir Çelenk, Hayrettin Yağcı, Suphi Aşıcı, Zihni İpek, Bekir Erdinç, Mehmet Cantaş, Hasan Congara, Abdi İnan, Yaşar Kalyoncu, Osman Manzak, İlhami Sağlamer, Rüştü Altınbaş, Mehmet Kapanoğlu, Hacı Kapazoğlu, İsmail Hac1 Süleymanağaoğju, İsmail Cevahir, Urfi Çetinkaya, Sadi Başkan, Niyazi Söylemez to surrender to the commandership. The bullies of the underground world know as the "papas" in the press were released after a while (Mumcu, 1994: 86). 
After the failure of the Third Papas Operation, another one started with the suggestion of National Intelligence Agency to the Presidency of General Staff for the interrogation of Dündar Kılıç, Behçet Cantürk, and Abuzer Uğurlu. Along with these names, 36 people were taken into custody and in the result of the interrogations, the operation was expanded 20.000 pages of testimonies were taken from 1500 people. Based on these testimonies, tens of lawsuit cases were opened and the hearings lasted for years (Erdinç, 2004: 231-232).

Due to consecutive operations, a majority of drug smugglers either escaped abroad, arrested, or preferred not to draw attention and stood back during the 1980s. In the year of 1985, 69 Turkish drug smugglers including names like Bekir Çelenk, Zihni İpek, and Avni Musullulu were sought by Interpol with the red notice. In 1987, police operations carried out one after the other in Europe struck a great blow on Turkish mafia; together with Hasan Heybetli and Oflu İsmail, 61 Turkish people alone were arrested in the operation carried out in Holland on 26 February (Erdinç, 2004: 267-9).

The operations carried out in two ships-Kismetim-1 and Lucky-S-loaded with drugs on 15 December 1992 and 7 January 1993 once again grabbed attention towards major drug traffickers and their connections within the state. The declaration of Hüseyin Baybaşin who claimed to smuggle drugs within the knowledge of higher-rank police officers Mehmet Ağar, Necdet Menzir and İsmet Sezgin caused the subject matter to be discussed longer and more loudly in the public. The claim that major drug smugglers and certain officers within the state work in collaboration is still a frequently discussed problem today (Erdinç, 2004: 278-281).

Turkish drug traffickers continued to remain significant names among world drug trafficking during the 2000s, too. Cumber Yakut, Urfi Çetinkaya, Cemal Nayır, Habip kanat, Abdullah Baybaşin, Halil Havar, Vahdet Daş, Nihat Dayan, Nasreddin Uçak, İslam Yakut, Selim Işık, Hurşit Yavaş are some of these figures. The drug traffickers who before were called "papas" started to be referred as "barons" since the early $1990 \mathrm{~s}$.

\section{METHOD}

This study investigates how the news about major drug smugglers, whom the media names as "barons" are presented. Our main starting point is how the drug smugglers named as barons are defined by the media, whether this definition encourages substance use or trafficking, in other words; whether the media carries out a sensitive perspective concerning the struggle against substance use and addiction. In this scope, news about people who smuggle a massive amount of drugs published between January-November 2016 on the websites of the three top-seller newspapers, Hürriyet, Sözcü, and Sabah, are analyzed within the framework of the critical discourse analysis developed by Teun A. Van Dijk. News published during the time period in question were analyzed with respect to their macro and microstructures, in the light of Van Dijk's discourse analysis method which examines the macro and microstructures of the news. While macrostructure analysis focuses on components like headings, introductions, main case presentation, news resources, background and context information; microstructure analysis deals with the syntax and word choices of the news (Van Dijk, 2007: 169170). Hence it is revealed how and in which context the media presents the news about major drug smugglers, named barons, which problems are brought up with these methods of presentation. Besides, thematic analysis was used in providing identification of around which themes contents that build certain meanings concerning "barons" are developed (Dursun, 2001: 201). In this context throughout the study the following questions will be investigated:

Around which themes is the "baron" discourse mainly developed in Turkish media? question?

How are the major narcotic/stimulant substance smugglers positioned within the discourse in

What are the meanings created within this discourse, and how?

Submit Date: 07.04.2018, Acceptance Date: 20.07.2018, DOI NO: 10.7456/10804100/009 


\section{FINDINGS}

In this section, news about people who smuggle massive amount of drugs, named "barons" by the Turkish media are analyzed within the framework of the critical discourse analysis developed by Dutch linguist Teun A. Van Dijk, and the findings are presented under the categories of findings concerning the macrostructure of the news and findings concerning the microstructure of the news.

\section{FINDINGS CONCERNING THE MACRO STRUCTURE OF THE NEWS}

Under the heading macrostructure analysis, contents like headings, news introductions, main case presentation, background and context information are addressed. The most attractive part of a newspaper article is the heading. The more striking the heading is, it is more probable that it will attract the reader's attention and hence will be read more. For newspaper texts, first, the headings are read and the remaining content is only read in the case of an interesting heading. Besides the information presented in the headings are quite significant in terms of making sense of the text and understanding the themes without reading the rest of the article (Işık and Eşitti, 2013: 154).

In the result of the analysis, it is revealed that in almost all of the news about major drug smugglers, the article headings consist of incidents of either capturing or prison-escape: "Baron from Çinçin escaped but then captured" (Hürriyet, 2016, July 7), "Baron from Çinçin managed to escape this time" (Hürriyet, 2016, July 7), "The same escape story of Drugs Doctor from Silivri Prison took place in England" (Hürriyet, 2015, March 28), "Jailbreak notice was faxed at 16.50" (Hürriyet, 2015, March 28), "Faxed release suspect turned out to be Havar's brother-in-law" (Hürriyet, 2015, March 26), "Evaporated from Silivri with a single fax" (Hürriyet, 2015, March 25), "Drug baron escaped from hospital" (Sabah, 2016, July 7), "Fugitive baron from Ankara was captured!" (Sabah, 2016, July 2), "Drugs baron was sent to his country!" (Sabah, 2016, July 2), "Drugs baron 'Snail' was captured" (Sabah, 2016, May 2), "Bonsai baron and his son were arrested" (Sabah, 2015, August 29), "Famous drugs baron was captured" (Sabah, 2015, April 21), "Shorty escaped prison again" (Sabah, 2015, July 13), "Guardian suspected for baron's escape" (Sabah, 2015, April 13), "How did baron escape, second-by-second" (Sabah, 2015, March 27), "Terrorizing baron was captured" (Sabah, 2015, March 6), "Instructions came from two European barons" (Sabah, 2015, January 28), "Fugitive baron sentenced to 18 years in prison" (Sabah, 2015, December 5), "The USA delivered Mexican baron to his country" (Sözcü, 2016, June 16), "The judge of drug baron Guzman was killed in the middle of the street” (Sözcü, 2016, October 19), "Drug baron escaped again” (Sözcü, 2015, July 12), “Guzman's escape video was published" (Sözcü, 2015, July 15).

In the headings listed above narcotic/stimulant substance smuggling is portrayed as an adventurous job, and likewise, smugglers are represented as cunning people. Furthermore, it is implied that jailbreak is an easy job for these people by presenting their cunningness and how easily they can escape prison with the help of their relationships with government officials. Hence, with the portrayal of jailbreak as a plain work renders the strictness of the punishment for narcotic/stimulant substance smugglers meaningless.

In headings like "Baron Hasan is free for 300 thousand Turkish liras!" (Hürriyet, 2015, August 14), and "Prince's friend is narcotics baron!" (Sabah, 2015, September 28) there is an implication that narcotic/stimulant substance smugglers are wealthy people and a further implied relationship between smugglers and statesmen is present. Besides, in headings such as "Baron Chapo is investing in football" (Hürriyet, 2016, January 15), it is revealed that the economic activities that the smugglers conduct with revenues from illegal transactions are normalized through conceptualization as "investment". Furthermore, the following headings "The shirt that drug baron Joaquin Guzman, a.k.a. 'the shorty' wears in his meeting with Sean Penn breaks sales record" (Sözcü, 2016, October 19), and "El Chapo literally became a trademark" (Sabah, 2016, January 31) reveal that narcotic/stimulant substance smugglers are presented as they can become popular people like artists or football players. 
Within the news schema, news introduction that comes after the heading is the part where the news article text is summarized and the main argument of the story is conveyed (Doruk, 2013: 118). In this section summary information that contains the overall structure and meaning of the news is presented, thus the reader is provided with an opportunity to understand the overall story (Iş̧1k and Eşitti, 2013: 154).

It is identified that just as in the headings, news introduction texts also present narcotic/stimulant substance smuggling as an adventurous job and therefore those who take part live their lives almost like in the movies:

In İzmit, leader of a criminal organization Arif Ötleş, brought from Kocaeli F-Type Prison to a hospital for his treatment, escaped by jumping out of the window. While three people who helped him are caught after the incident, the suspect fled on a motorbike. Ötleş, whose vehicle broke down in Hendek district of Sakarya and 4 his men that he called from Ankara were captured during police control. While Arif Ötleş was neutralized by the police, he ordered his man to shoot the police (Hürriyet, 2016, July 2).

Deep relations were detected in Akgün murder. The order of assassination in İstinye was claimed to be given by 2 drug barons in Europe (Sabah, 2016, January 28).

The details of drug baron's escape from prison with a fax resembled a movie scene...(Sabah, 2016, March 27).

...In spite of the movie-like escape of brothers-in-law...(Hürriyet, 2015, March 26).

Last week, the world's richest drug baron Joaquin Guzman was caught in an operation that resembled adventure movies...(Hürriyet, 2015, January 15).

Mexican drug baron Joaquin Guzman escaped from the maximum security prison twice (Sözcü, 2016, July 12).

Besides, it is revealed that drug smugglers named "barons" are presented as quite cunning people. This situation was especially apparent in the news about the prison break incident of Doğan Alagöz:

It turns out that the escape of Doğan Alagöz with a fake release verdict faxed to Silivri Prison was subtly planned, and that the fax was sent at 16.50 just before the shift change so that the fake document would not be revealed (Hürriyet, 2015, March 26).

Doğan Alagöz, who escaped with a fake release verdict from the prison where he was convicted due to the production of drugs turned out to be Halil Havar's brother-in-law, who 24 years ago had escaped from the prison in Holland with a helicopter. In spite of the movie-like escape of brothers-in-law, Alagöz escaping without any expenditure except for a fax and a phone call reminded us the saying, "In 24 years the student became the teacher" (Hürriyet, 2015, March 26).

The details of drug baron's escape from prison with a fax reminded the movie scenes. The fax was sent 10 minutes before the shift change. The prison was called and forced. Baron was released in 2.5 hours (Hürriyet, 2015, March 26).

Along with these, that drug smuggling is a profitable business was conveyed as a message in the news introductions, too:

Last week, the world's richest drug baron Joaquin Guzman who was caught in an operation that resembled adventure movies, decided to buy a club in Europe (Hürriyet, 2016, January 15).

Just as the headings and news introductions, the idea that narcotic/stimulant substance smuggling is a quite adventurous and profitable business, and that smugglers are cunning, wealthy people whose lives resemble movie characters are presented within the news article texts, too. The findings suggest that news texts are written like film scenarios and the abundance of details help reader to feel himself/herself inside the story. While the escape story of Arif Ötleş is conveyed with deliberate

Submit Date: 07.04.2018, Acceptance Date: 20.07.2018, DOI NO: 10.7456/10804100/009 
details, describing what happened during the strife between security forces, the attitude of Ötleş's men and even the vehicles' registration plates; there is hardly any information about the magnitude of social harm given due the drug smuggling he was involved, thus his smuggling was transferred as a regular issue or a simple problem in public order. A similar situation was observed in Doğan Alagöz news story; while there are many details about how Alagöz escaped from the hospital, how the incident took place instant by instant and even much irrelevant information about how his brother-inlaw Halil Havar escaped back in 1991; there is almost no evidence of historical, social, and economic reasons for the event. The same is applicable for the news about the capturing and escaping of Colombian drug smuggler "Chapo" (shorty) Joaquin Guzman.

Another significant finding of the study is that drug smugglers called "barons" become subject to the news in using certain nicknames and expressions that implement positive meanings. Within this framework the following headings were detected: "Baron from Çinçin" for Arif Ötleş (Hürriyet, 2016, July 2), "World's richest drug baron Chapo (shorty)" for Joaquin Guzman (Hürriyet, 2016, January 15), "One of the most famous drug barons of Mexico Shorty/El Chapo" (Sabah, 2015, March 28), "Drugs Doctor" and "Synthetic Baron" for Doğan Alagöz (Hürriyet, 2015, March 28), "Marvelous Turk" for Halil Havar (Hürriyet, 2015, March 26), "First Turk to escape prison on a helicopter" (Hürriyet, 2015, March 28), and "Caracol (Snail)” for Gerson Galvez (Sabah, 2016, May 2).

In news texts, the presence of information that will contribute to making sense of the news, explain the background of the event is quite significant for the reader to truly understand the incident. However, information concerning the background and context of the event as seen in the texts above is either inadequate or completely nonexistent. The use of background and context information at this level and in such manner result in the decontextualization of the event subject to news and reusing of frameworks that were utilized in the presentation of similar past events. In this case, the news source's comments the main event and its consequences become mainly what constitutes the entire text (İnal, 1995: 118-119). It is detected that the analyzed texts lack background and context information but rather contain an overemphasized content of the main event and its adventurous consequences. Thus narcotic/stimulant substance smuggling crime which constitutes the base of a quintessential social problem such as substance use and addiction is decontextualized and transformed into a lucrative and adventurous activity.

\section{FINDINGS CONCERNING THE MICRO STRUCTURE OF THE NEWS}

In microstructure analysis, the reflections of the discourse on the units of language are investigated. Word choices, syntax, causality relationship between the sentences are analyzed associated with rhetoric (Van Dijk, 1988). Within this framework under this subheading, sentence structures (syntactic analysis) and word choices are examined.

In the syntactic analysis, the ideological nature of the news is revealed considering the length, complexity, and activeness of the sentences (Keskin, 2004: 393). In this scope, throughout the study the structure of the sentences used in news texts, in other words how the sentences are formed, activeness and passiveness of the verbs, and how the subject of the sentence is position are analyzed (Aygün, 2011: 228) and with the analysis of active/passive structures the agent(s) that carry out the action are detected.

The findings reveal that the actions carried out by the smugglers are expressed in active voice in news about drug smugglers. Active sentence structure is especially preferred in news that contain the smugglers' crimes, escape incidents and the amount of drugs they had on when they were captured. Thus activities like smuggling great amounts of drugs, owning a great fortune, involving in murder, forcing to pay protection money, escaping from prison; which in the criminal world are known as activities that bring reputation are expressed along with the actors who carried them out thus in a way bringing prestige to these individuals. On the other hand, passive sentence structure is used in news about the narcotic/stimulant substance smugglers' strife with security forces or in cases where they are

Submit Date: 07.04.2018, Acceptance Date: 20.07.2018, DOI NO: 10.7456/10804100/009 
in conflict: as seen in the quote from a news "A gendarmerie officer was wounded during the strife" (Hürriyet, 2016, July 2); in the case of the injury of a gendarmerie in a strife where the smuggler or his allies are involved, the agent is made vague.

The activities carried out by security forces or public servants are generally expressed in passive voice: "...convicted to life sentence...wounded in Sakarya...captured with 4 his men in the vehicle...Ötleş was caught while attempting to escape from İzmir to Greece" (Hürriyet, 2016, July 2), "...Joaquin Guzman was caught in the operation conducted last week" (Hürriyet, 2016, January 15), "caught in the house where he was hiding" (Hürriyet, 2016, August 14), “...it turns out that he returned willingly" (Hürriyet, 2016, August 14), “...sent to Altiplano Hospital” (Sözcü, 2016, June 16), "Guzman was caught due to his desire for fame" (Sözcü, 2016, January 10), "3 suspects were taken into custody" (Sabah, 2016, July), "Fugitive baron from Ankara was captured" (Sabah, 2016, July), “...was sued" (Sabah, 2015, December 5) etc. and many other news texts reveal this situation. This choice is evaluated as the effort to prevent the revealing of security forces' identities.

Word choice is also significant in the microstructure analysis of the news. As Van Dijk stated, the word choices within the news reflect an ideological attitude. To him, the use of terms "terrorist" or "freedom fighter" reveals the ideological standpoint of the reporter or editor (Van Dijk, 1988: 28). In the light of the analysis made, it is detected that three of the top-seller newspapers in Turkish media prefer the term "baron" for people who smuggle great amounts of narcotic/stimulant substances and with a use that associates the word with positive meanings, and the consequence is an inattentive use of language concerning the struggle against the use and addiction of drugs. The language of narration, positioning of the actors, nicknames used, lack of emphasis on social and economic problems that occur as a result of the smuggling activities when analyzed together, consequently reveal a noncoincidental use of a certain tone. While the media uses the term "poison merchant" even for kids who are pushed to criminal activities concerning narcotics/stimulants (Işık, 2016: 143-157), the preference of the concept "baron" when it's about people who engage in massive amounts of drug trafficking reveals a necessity to question its sincerity concerning the struggle against substance use and addiction.

\section{DISCUSSION AND MEDIA OBSERVATORY SUGGESTION}

As put forward in this study and in many other studies before (Iş1k, 2013; 2013a; 2016), although much is expected from the media in the struggle against use and addiction of drugs, though suggestion decisions are taken, and even though leading principles are determined, the media refuses to concur. At this point, the major problem is evaluated to be the lack of establishment of an institution/structure that will control whether media concurs with the advice and leading principles present and inculcate in this direction.

Media, by nature, utilizes writing and presentation methods that would attract the target audience, hence aims to extend viewers/readers. However, media should not emphasize only the attractive aspects of events while reporting the news, instead, it should broadcast with a consciousness of social responsibility. As a matter of fact, media is criticized both in Turkey and the world for not fulfilling its responsibilities.

The four titles that media was criticized under were listed in the report "A Free and Responsible Press" prepared by Hutchins Commission in 1947. They are "1-Media exploits its power and position. 2-Media has become a servant for major commercial companies. 3-Advertisers have come to a position that controls the press. 4-Media as a medium is used not to inform the public but to create a sensation." (Öztürk, 2007: 15) The criticism of Hutchinson Commission still prevails today.

The frequent use of attractive and sensational news by the media or emphasizing the insignificant sensational aspects of the news usually results in the sociological, psychological, economic, and social

Submit Date: 07.04.2018, Acceptance Date: 20.07.2018, DOI NO: 10.7456/10804100/009 
aspects of events to be ignored. This consequently prevents the public to be informed about facts and weakens the claim that media reports news for the sake of the public. Besides, media most frequently utilizes encouraging, affirmative statements while reporting news about crime and criminals so that the news would become more attention getting. In the result of the criticisms directed at the media, Social Responsibility model was developed and the following responsibilities are argued to be fulfilled by the media (Öztürk, 2007: 15):

"-(Media) should be attentive to be informative, objective and report in accordance with facts and balance,

-While the responsibilities are fulfilled the press should limit itself in accordance with the law, minorities,

- Media should refrain from encouraging reports and offensive policies towards

—Public well-being should be overseen by the media."

Social Responsibility model refuses the idea that media institutions should be controlled by the government; instead, it argues that media should be controlling itself. As revealed in this study, media remains inattentive in fulfilling the responsibilities listed above. This situation unveils a significant problematique: If it is not the government who will inspect the media, if there will be no auto-control mechanism; whose responsibility then it will be to present the necessary information, notice, and suggestions to the media? This question can be answered inspired from Ignacio Ramonet's (2004) "Media Observatory" suggestion.

Ramonet argues "the news poison our minds, pollute our brains, manipulates us, and slowly processes ideas that do not belong to us into our subconscious" therefore there is a need for a "news ecology"; he claims that an international media observatory should be established and the news feed should be controlled (Ramonet, 2004). To him, "Freedom of the press is the extension of common freedom of expression that is the basis of democracy" and the people "should not tolerate the destruction of this freedom by a group of the powerful". Such a freedom "requires social responsibility and therefore its application must be under the responsible control of the society" (Ramonet, 2004). In this regard, controlling the contents presented by the media while protecting its freedom and establishing a mechanism that regularly informs and check on the media is only possible with a structure built by the civil society. Ramonet (2004), argues that the International Media Observatory should consist of the following groups:

"1—Professional or freelance journalists who still work in or are retired from either mainstream or alternative media,

2-Academicians, researchers, and especially media experts-since universities are one of the few institutions though partially protected from the totalitarian ambitions of the market, behavior."

3-Media users, regular citizens, and public figures who stand out with their moral

Based on this suggestion of Ramonet, the foundation of a nation-wide media observatory that examines the news about substance use and addiction is predicted to contribute a great deal to the solution of the problem. This media observatory member of which will be determined in the light of Ramonet's suggestion will be able to inform and notice reporters and gatekeepers in regularly examining the news about substance use and addiction. This will minimize the negative effects of the media.

\section{CONCLUSION}

In this study that questions the sincerity of Turkish media's support to the struggle against substance use and addiction within the framework of the concept "baron", news about smugglers of great

Submit Date: 07.04.2018, Acceptance Date: 20.07.2018, DOI NO: 10.7456/10804100/009 
amounts of narcotic substances on the websites of the three of the top-seller newspapers; Hürriyet, Sözcü, and Sabah published between January-November 2016 are analyzed according to the critical discourse analysis developed by Teun A. Van Dijk.

The results of the analysis reveal that the news about people who smuggle drugs and who are named as "barons" by the Turkish media are transferred to the reader with an encouraging and exaggerated use of language, that drug trafficking is represented as a quite lucrative and adventurous profession which provides opportunities to quickly promote or possess fame and fortune, that instead of focusing on personal, social, and economic problems caused by drug trafficking, the problem is decontextualized by putting the emphasis on individual success stories of barons, the magnitude of smuggling, how cunning the smugglers are, how they could escape from prison or how they lived in their ordinary lives. While the media uses the term "poison merchant" even for kids who are pushed to criminal activities concerning narcotics/stimulants, the preference of the concept "baron" when it's about people who engage in massive amounts of drug trafficking reveals a necessity to question its sincerity concerning the struggle against substance use and addiction. Hence from this perspective, the "baron" discourse functions as a litmus paper in the sense of Turkish media's sincerity concerning its struggle against substance use and addiction. Besides, the results also reveal that the media remains inattentive in considering the principles stated in the booklet Audiovisual Media's Role in Substances and Substance Use and the later published Communication Strategy Application Guide For The Fight Against Drugs Action Plan.

Media, by nature, presents the subjects it deals with to the reader in an attractive manner, notwithstanding usually ignores an understanding of social responsibility. One of the most significant problems here is the lack of an institution structure that will control whether media concurs with the principles suggested in the guiding study mentioned and will warn media to adjust to the suggestions. It is evaluated that in order to effectively contribute to media's involvement in the struggle against substance use and addiction, further studies should discuss the "media observatory" structure and the scope of its authority.

\section{REFERENCES}

Abrams, F. (2005). Speaking Freely: Trials of the First Amendment. New York: Penguin Books. Aydoğdu, M. (2015). Ortaçă̆ Feodal Mülkiyet Anlaylşı ve Osmanlı Hukukundaki Toprak Sisteminin Türk Hukukundaki Tarımsal Işsletmelerin Mirasçılara Ö̈gülenmesine Etkileri. D.E.Ü. Hukuk Fakültesi Dergisi, 17 (2), 1-26.

Aygün, E. (2011). Yazılı Basın Haber Söylemlerinde Cumhuriyet Mitinglerinin Sunumu Yayımlanmamış Yüksek Lisans Tezi. Ankara: Ankara Üniversitesi Sosyal Bilimler Enstitüsü.

Dursun, Ç. (2001). Tv Haberlerinde İdeoloji, Ankara: Imge Kitabevi.

Erdinç, F.C. (2004). Overdose Türkiye: Türkiye'de Eroin Kaçakçılığı, Bağımlılı̆̆l ve Politikalar. İstanbul: İletişim.

Erhan, Ç. (1996). Beyaz Savas: Türk-Amerikan İlişkilerinde Afyon Sorunu. İstanbul: Bilgi Yayınevi.

Eşitti, Ş. (2013). Gözetim Toplumunda Sinoptikon ve Sosyal Medya. Yayımlanmamıs Doktora Tezi. Marmara Üniversitesi Sosyal Bilimler Enstitüsü Iletişim Bilimleri Anabilim Dall

Gingeras, R. (2014). Heroin, Organized Crime, and the Making of Modern Turkey. Oxford: Oxford University Press.

Goloğlu, M. (2010). Türk Devrim Tarihi. Trabzon: Karadeniz Teknik Universitesi Y.

Inal, Ayşe. (1995). Yazıll Basın Haberlerinde Yapısal Yanlılık Sorunu. Toplum ve Bilim, 67, 111 135

Işık, M. (2013). Madde Kullanımı ve Stratejik İletişim. Ankara: Sage Yayınları.

Işık, M. (2013a). Türkiye’nin Madde Kullanımı ve Bağımlılı̆̆ ile Mücadele Politikasının Stratejik İletişim Yaklaşımı Çerçevesinde Değerlendirilmesi, Yayımlanmamış Doktora Tezi. İstanbul: Marmara Üniversitesi Sosyal Bilimler Enstitüsü.

Submit Date: 07.04.2018, Acceptance Date: 20.07.2018, DOI NO: 10.7456/10804100/009 
Işık, M. (2016). Uyuşturucu ve Uyarıcı Maddelerle İlgili Suçlara Karışan Çocuklara İlişkin Haberlerin Yazılı Basında Sunumu. Ayşe Çolpan Kavuncu (Der.), Kentsel Güvenlik ve Çocuk Suçluluğu (s.143-157). Ankara: Polis Akademisi Yayınları

Işık, M. ve Erdal, H. (2015). Türkiye'nin Madde Kullanımı ve Bă̆ımlıll̆̆̆ ile Mücadele Politikasının Değerlendirilmesi ve Yeni Bir Model Önerilmesi, Turkish Studies/International Periodical for the Languages, Literature and History of Turkish or Turkic, 10(2), 461-482, DOI Number: http://dx.doi.org/10.7827/TurkishStudies.7552.

Işıl, M. ve Eşitti, Ş. (2013). Venezuela'da Gerçekleşen Nisan 2002 Askeri Darbesinin Yazılı Basında Sunumu. Uluslararası Sosyal Araştırmalar Dergisi. Vol. 6/28, s. 146-165. ISSN: 1307 -9581

Mumcu, U. (1993). Papa-Mafya - A ğca. İstanbul: Tekin Kitabevi

Mumcu, U. (1994). Silah Kaçakçıllı̆̆ ve Terör. İstanbul: Tekin Kitabevi

Öztürk, O. (2007). Demokrat Parti Dönemi Basın Rejimi ve Zafer Gazetesi (1957-1960) Ulus Gazetesi İle Karşılaştırmalı Bir İnceleme. Yayımlanmamış Yüksek Lisans Tezi. Ankara Üniversitesi Sosyal Bilimler Enstitüsü. Ankara

Parlar, S. (2006). Kirli İ̧̧ler İmparatorluğu: Uyuşturucu Kaçakçıllı̆g, Mafya, Devlet. İstanbul: MEP Kitap

Pek, A. \& Pinarcl, M. \& Demirci, B. \& Ayhan D. \& Öztürk, N. \& Yardımcl, N. \& Emirhan, A. ve Diler, M. (2010). Madde ve Madde Kullanımında Görsel ve İsitsel Medyanın Rolü Etik Kitapcık, Ankara: RTUK-EGM Ortak Yayını.

Poroy, $\dot{I}$. (1981). Expansion of Opium Product in Turkey and State Monopoly of Opium Straw 18281839. International Journal of Middle East Studies. 13, 191-211.

Ramonet, I. (2004). "Beşinci Kuvvet", Çev. Y. İnceoğlu, N. Akıner, U.U. Aydın, Varlık Dergisi. s. 3-7 Songar, A.(1974). Haşhaş Meselesi ve Türkiye. Istanbul: Hareket Yayınlart

UNODC. (2016). World Drug Report. New York: United Nations Publication, https://www.unodc.org/doc/wdr2016/WDR 2016 Chapter 1.pdf, erişim 18.10.2016

Ünüvar, N. (2008). (Ed.). TBMM Uyuşturucu Başta Olmak Üzere Madde Bağımlılı̆̆ Ve Kaçakçıllğı Sorunlarının Araştırılarak Alınması Gereken Önlemlerin Belirlenmesi Amacıla Kurulan Meclis Araştırma Komisyon Raporu. Ankara: TBMM Yayını.

Van Dijk, T. (1988). News as Discourse. New Jersey: Lawrence Earlbaum Associates Publication Van Dijk, T. (2007). Bir Söylem Olarak Haberin Disiplinlerarası Çözümlenmesi, G. Şendur Atabek ve Ümit Atabek (Der.), Medya Metinlerini Çözümlemek, Ankara: Siyasal Kitabevi

Zürcher, E. J. (2011). Modernleşen Türkiye'nin Tarihi. İstanbul: Illetişim 